\title{
Improving output current of inductor-cell based five-level CSI using hysteresis current controller
}

\author{
Suroso, Winasis, Priswanto, Sholikhah \\ Department of Electrical Engineering, Jenderal Soedirman University, Purbalingga, Indonesia
}

\begin{tabular}{l} 
Article Info \\
\hline Article history: \\
Received May 20, 2020 \\
Revised Jan 19, 2021 \\
Accepted Feb 2, 2021 \\
\hline
\end{tabular}

\section{Keywords:}

Inverter

Power inductor

Ripple

\begin{abstract}
Current source inverter (CSI) operates to output a specified ac current waveform from dc current sources. Talking about power quality, harmonics distortion of ac waveform is a problem of an inverter circuit. Generating a multilevel current waveform will have less harmonics content than a traditional three-level current waveform. In addition to non-ideal conditions of power switches, i.e. voltage drop in diodes, conductors or controlled switches, the performance of current controller applied in an inverter circuit will considerably affect the ac waveform quality produced by inverter circuit. This paper presents and discusses application of hysteresis current controller in the five-level $\mathrm{H}$-bridge with inductor-cell current source inverter. The current controller performance was compared with the proportional integral current controller. Some test results are presented and discussed to explore the advantages of hysteresis controller in reducing the current ripple and harmonics distortion of output current.
\end{abstract}

This is an open access article under the CC BY-SA license.

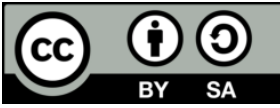

\section{Corresponding Author:}

Suroso

Department of Electrical Engineering

Jenderal Soedirman University

Jl. Mayjen Sungkono km. 5, Blater, Purbalingga, Jawa Tengah 53371, Indonesia

Email: suroso.te@unsoed.ac.id

\section{INTRODUCTION}

Power inverters generating three or more level ac waveform called as multilevel inverters [1]-[3]. The produced waveform has less harmonics content, less voltage or current stress, and it needs smaller size of output filter. Multilevel inverter circuit generating a multilevel voltage waveform known as multilevel voltage source inverter (VSI). Whereas, a multilevel inverter producing a multilevel current waveform classified as multilevel current source inverter (CSI) [4]-[6].

In some utilizations as in high power ac motor drive, and renewable power generation, current source inverter offers some merits than its dual, voltage source inverter. Driving ac motor using current source inverter will give benefit such as less stress of motor's winding insulation, because the voltage waveform has less dv/dt [7]-[11]. In the renewable power generation application, current source inverter has natural boost up voltage capability that can not be obtained using voltage source inverter [12]-[17].

Generating an ac current waveform with minimum harmonics content is an important aspect in development of a current source inverter [18]-[20]. Increasing the level number of ac current is a good alternative solution. However, it will introduce another problem such as increasing circuit complexity of inverter [21]-[24]. Another approach is by increasing the output filter size of inverter. Nevertheless, it will augment the size and cost of inverter circuit [25]-[27]. Implementing an effective controller is another alternative to address this power quality problem [28]-[35]. 
This paper discussses an implementation of hysteresis current controller in an inductor-cell based five-level CSI circuit. The current controller was tested and examined to explore its performance. Furthermore, the hysteresis current controller was compared with the proportional integral (PI) current controller in order to investigate the effectivity of current controller in reducing the current ripple and harmonics level of the inverter's output current waveform.

\section{INVERTER CIRCUITS}

Figure 1 presents a configuration of five-level CSI constructed by using H-bridge and inductor cell circuits previously developed by author in [18]. The circuit is able to generate a five-level current waveform from the three-level current generated by the H-bridge inverter through energizing and de-energizing operations of inductor, $\mathrm{L}_{\mathrm{c}}$. While, the main dc input current is generated by the switch $\mathrm{Q}_{\mathrm{c}}$, and diode $\mathrm{D}_{\mathrm{f}}$ from dc power source, $V_{\text {in. }}$. The current magnitude of $\mathrm{I}_{\mathrm{Lc}}$ is controlled to achieve a five-level ac current waveform generation. In this case, the current magnitude of inductor-cell is adjusted as a half of dc current, $\mathrm{I}_{\mathrm{Li}}$. Ideally, the inductor current is a constant dc current with no ripple. However, because of finite inductor size, the ripple of current will appear. Ripple of current flowing thru inductor cell $\left(\Delta \mathrm{L}_{\mathrm{c}}\right)$ can be calculated as (1):

$$
\Delta I_{L c}=\frac{I_{L c} \cdot R}{f_{s} \cdot L_{c}}
$$

In (1), $\mathrm{I}_{\mathrm{LC}}$ is the current of inductor cell, $\mathrm{f}_{\mathrm{s}}$ is the operation frequency of power switches, and $\mathrm{R}$ is the load resistance [18]. From this equation, we can minimize the current ripple by increasing the inductor size, or speed up the switching frequency. However, enlarging the inductor size will increase volume and weight of inverter. While increasing the switching frequency will escalate more energy losses caused by switching losses.

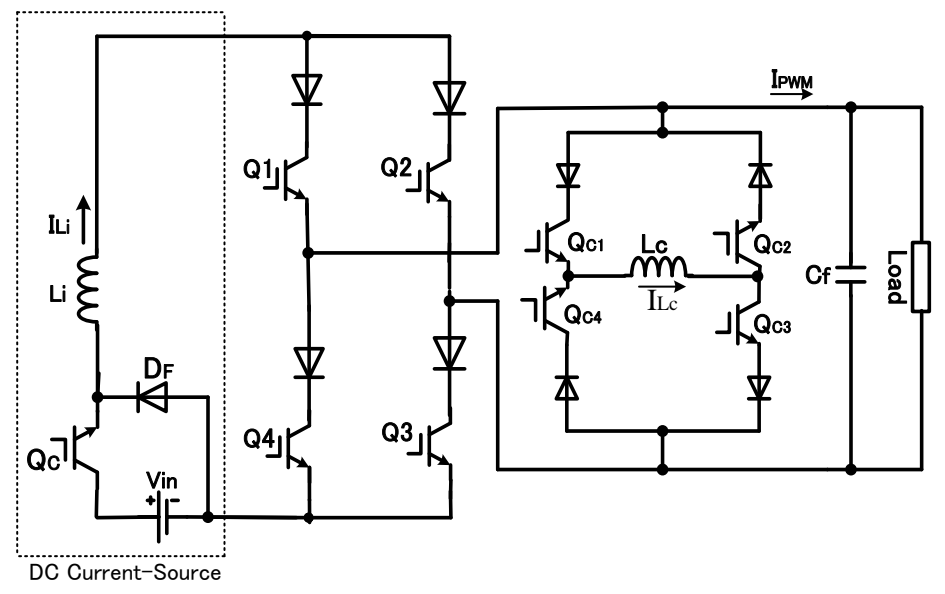

Figure 1. Five-level Inverter Circuits [18]

Figure 2 presents the previously implemented proportional integral (PI) current controller employed to govern the current flowing in the inductor $\mathrm{I}_{\mathrm{Lc}}$ [18]. Errors between the reference and actual currents were processed by PI gain stage. The output signals of PI controller were modulated by the triangular signal with constant frequency and amplitude as shown in the figure. Selection of energizing and deenergizing operations of inductor $\mathrm{I}_{\mathrm{Lc}}$ was also determined by this current controller. Gains of the PI controller $\mathrm{K}_{\mathrm{p}}$ and $\mathrm{K}_{\mathrm{i}}$ were determined to achieve a good performance of current controller by considering the time response, and ripple factor of inductor current which can be determined as (2) (3):

$$
\begin{aligned}
& K_{p}=\frac{L_{t} \cdot \omega_{c r}}{2 V_{i n}} \\
& K_{i}=\omega_{c r} \cdot K_{p}
\end{aligned}
$$


of which $\mathrm{K}_{\mathrm{p}}$ and $\mathrm{K}_{\mathrm{i}}$ are the proportional and integral gains, respectively. $\mathrm{L}_{\mathrm{t}}$ is total inductance seen by inverter, $\omega_{\mathrm{cr}}$ is the triangular frequency, and $\mathrm{V}_{\mathrm{in}}$ is input voltage of inverter circuit.

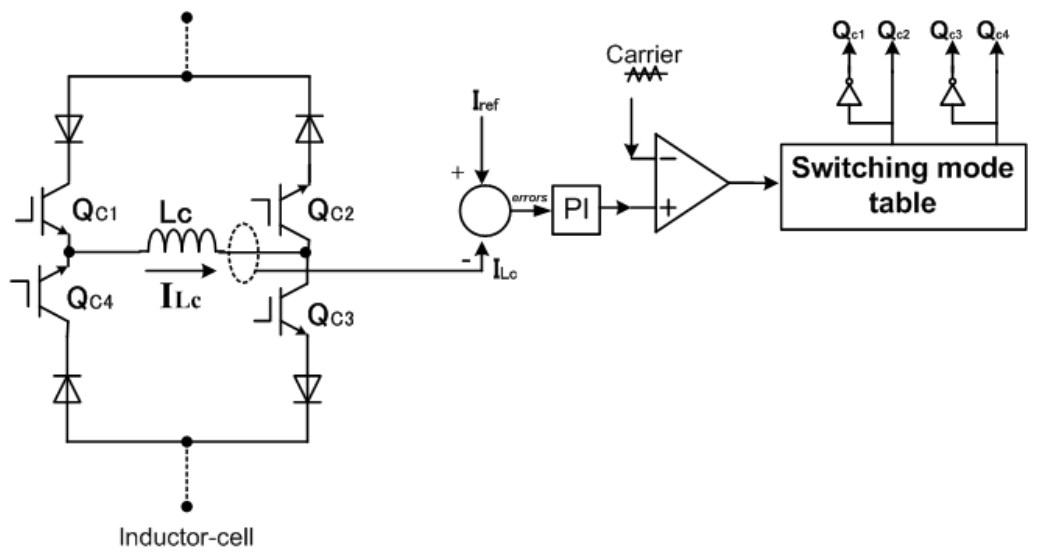

Figure 2. Proportional-integral current controller [18]

Figure 3(a) is the proposed hysteresis current controller which was used to set the current flowing in the inductor $\mathrm{I}_{\mathrm{Lc}}$. This controller replaced the PI current controller of inverter circuit in Figure 2. No triangular carrier was needed to modulate the output signal of hysteresis controller. The hysteresis band of the controller was varied to achieve smaller ripple of the current $\mathrm{I}_{\mathrm{Lc}}$. Figure 3(b) presents the principle work of the hysteresis current controller applied in the inverter circuits. $\mathrm{I}_{\mathrm{ref}}$ is the refence current controller, while $\mathrm{I}_{\mathrm{Lc}}$ is the actual current thru inductor-cell. This current fluctuates in a hysteresis band $\Delta \mathrm{I}$, or within upper and lower hysteresis limits. The PWM output signals will regulate the operation of power switches of inductorcell circuit. The transistors were switched turn-ON and turn-OFF if the actual current surpasses the hysteresis band. The implemented PWM modulation technique was the same with the inverter circuit applying PI current controller. So the basic difference is only in the current controller. In a hysteresis current control, switching frequency is not fixed, however its maximum $\left(f_{\max }\right)$ value can be determined as (4):

$$
f_{\max }=\frac{V_{\text {in }}}{\Delta I \cdot L_{t}}
$$

From (4), the hysteresis band $(\Delta \mathrm{I})$ can also be determined. In this case, the maximum switching frequency $\left(f_{\max }\right)$ is the main constraint related to the switching frequency ability of the power switches of inverter circuit. High speed power switches such as power MOSFETs will be suitable for smaller hysteresis value than IGBTs.

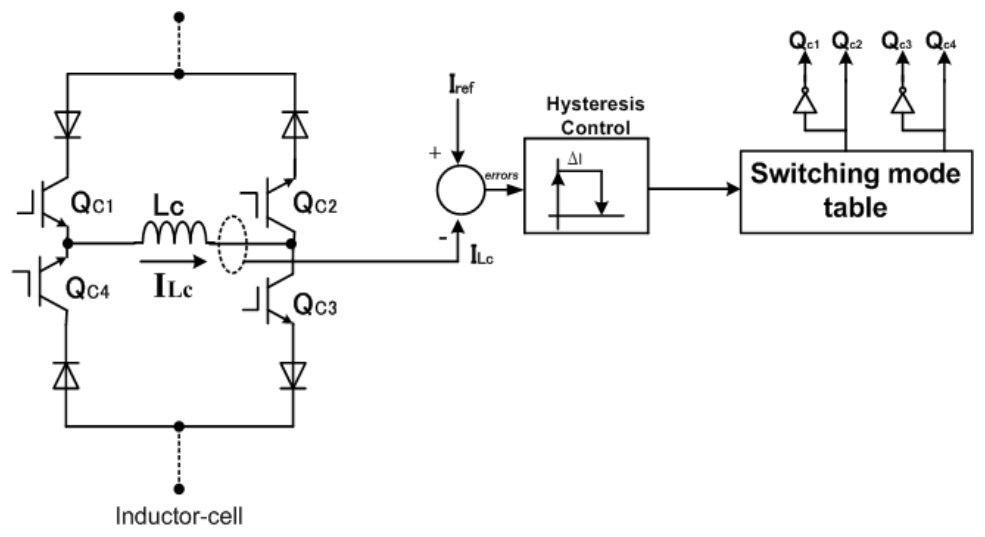

(a) 


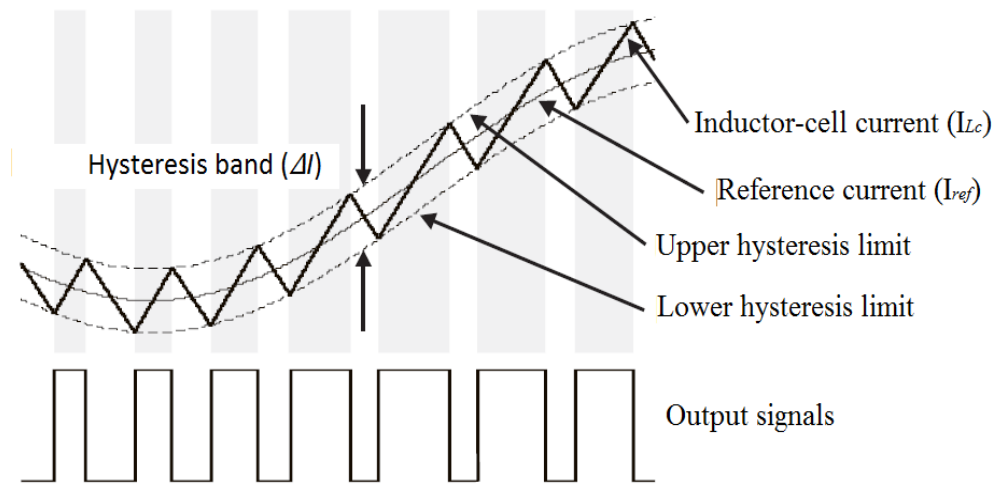

(b)

Figure 3. (a) Hysteresis current controller, (b) Its principle work

\section{RESULTS AND DISCUSSION}

To verify the performance of two current controllers, some computer simulations were conducted. The test parameters of power inverter are detailed in Table 1. The circuit was tested using power PSIM software. Two current control methods were separately implemented to adjust the current in the inductor cell, $\mathrm{I}_{\mathrm{Lc}}$, i.e. PI current controller and hysteresis one.

Figure 4 shows the test results indicating a five-level PWM current $\left(\mathrm{I}_{5 \text { Level }}\right)$, load current $\left(\mathrm{I}_{\text {Load }}\right)$ and the current of the inductor cell $\left(\mathrm{I}_{\mathrm{Lc}}\right)$ when PI current controller was employed. In this test, the gain of the PI controller was 90 with time constant value $0.1 \mathrm{~s}$. A five-level, and a pure sinusoidal current were produced properly by inverter circuit. The enlarged figures of inductor-cell current waveform including the start-up transient were shown in Figure 5(a) and 5(b). Result of settling time measurement of current $\mathrm{I}_{\mathrm{Lc}}$ was $0.0014 \mathrm{~s}$ with maximum transient current magnitude $4.1 \mathrm{~A}$ during starting of inverter circuit. While the ripple factor of current $\mathrm{I}_{\mathrm{Lc}}$ was $3.75 \%$.

Table 1. Test parameters.

\begin{tabular}{lc}
\hline \multicolumn{1}{c}{ Parameters } & Value \\
\hline DC smoothing inductor, $\mathrm{L}_{\mathrm{i}}$ & $1 \mathrm{mH}$ \\
Inductor cell, $\mathrm{L}_{\mathrm{c}}$ & $5 \mathrm{mH}$ \\
Carrier frequency & $22 \mathrm{kHz}$ \\
Main frequency & $60 \mathrm{~Hz}$ \\
DC power source, $\mathrm{V}_{\text {in }}$ & $160 \mathrm{~V}$ \\
Capacitor filter, $\mathrm{C}_{\mathrm{f}}$ & $5 \mu \mathrm{F}$ \\
Load & Resistor $8 \Omega$, inductor $1.2 \mathrm{mH}$ \\
\hline
\end{tabular}
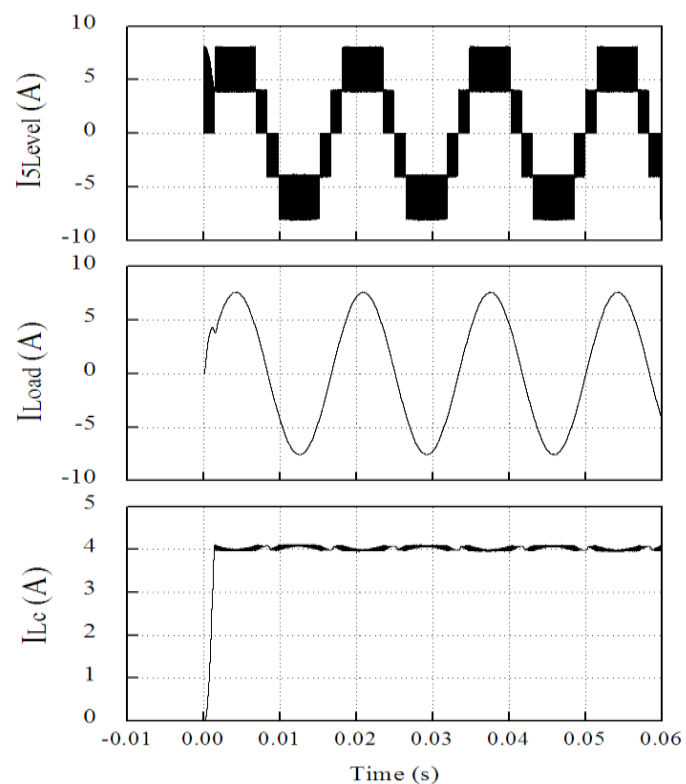

Figure 4. Five-level, load current and inductor cell current using PI current controller

To investigate the harmonics content of the PWM output current, Figure 6 presents the spectrum analysis of harmonics of the PWM current waveform. The highest magnitude of the low frequency harmonics 
component was the $7^{\text {th }}$ order. Its value was about $0.1 \%$. All magnitudes of low frequency harmonics components were less than $1 \%$. The measured THD value of the load current was $0.59 \%$.

Furthermore, Figure 7 shows the test results of inverter circuit when hysteresis current controller was applied. The hysteresis band of the controller was set at 0.02A. A five-level PWM, and pure sinusoidal current waveforms were also generated well using this controller. The close-up figures of the inductor-cell current waveforms were presented in Figure 8. The waveform includes the start-up transient of inductor-cell current. For this controller, the measured settling time was $0.0013 \mathrm{~s}$, while the ripple factor of current $\mathrm{I}_{\mathrm{Lc}}$ was $1 \%$. Hence, compared with the proportional integral current controller, the settling time of hysteresis current controller was faster than PI current controller. In another word, the PI current controller response was slower than the hysteresis current controller. In case of ripple factor of inductor cell current, the hysteresis current controller was only $1 \%$. The result was also much better because its ripple was much smaller than the ripple factor in the PI current controller, i.e. 3.75\%. The maximum magnitude of inductor-cell transient current during starting was also smaller than the PI current controller. Its value was around $4.02 \mathrm{~A}$, only. It was 0.08 $A$ lower than the PI controller.

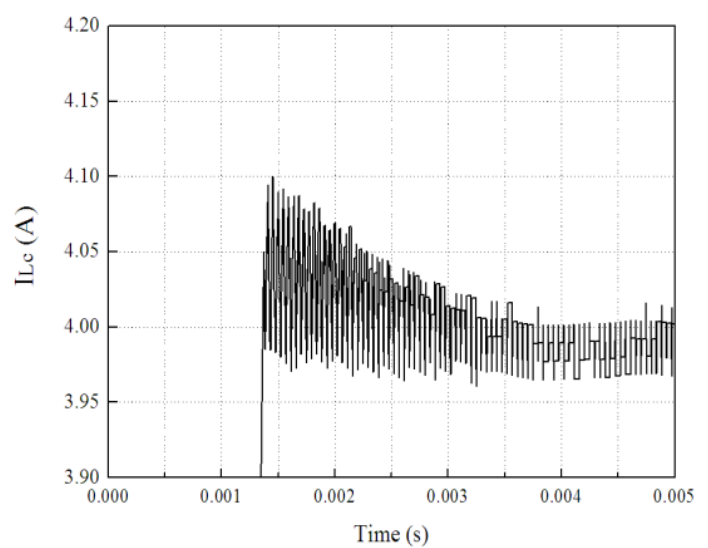

(a)

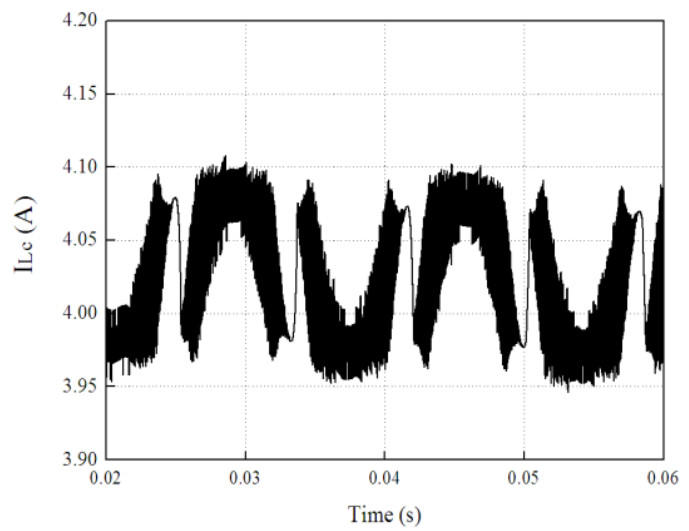

(b)

Figure 5. (a) Enlarged inductor cell current using PI current controller during start-up transient, (b) enlarged ripple of inductor cell current

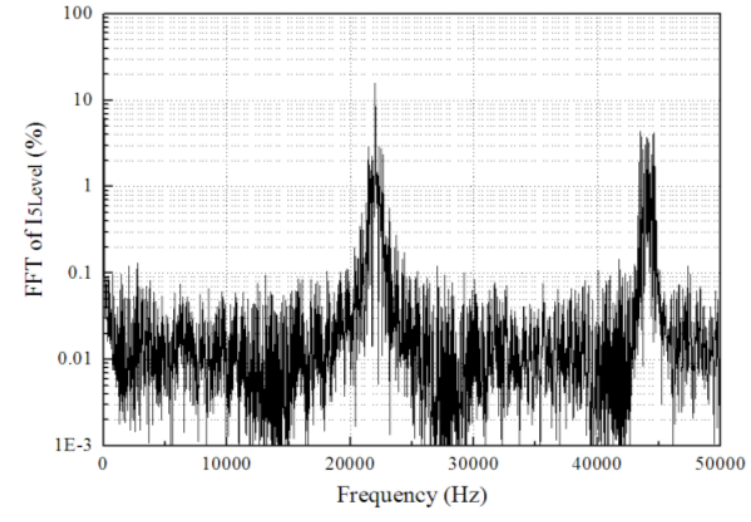

(a)

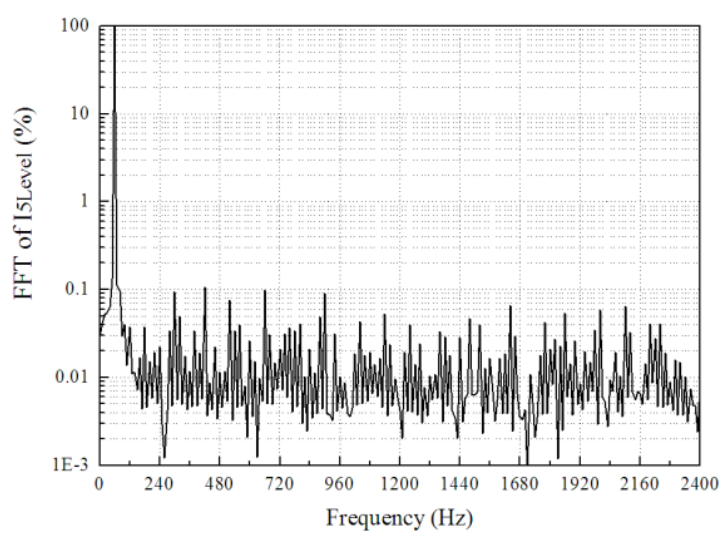

(b)

Figure 6. Harmonics content of five-level PWM current: (a) frequency range 0-50 kHz, (b) frequency range $0-2400 \mathrm{~Hz}$ 


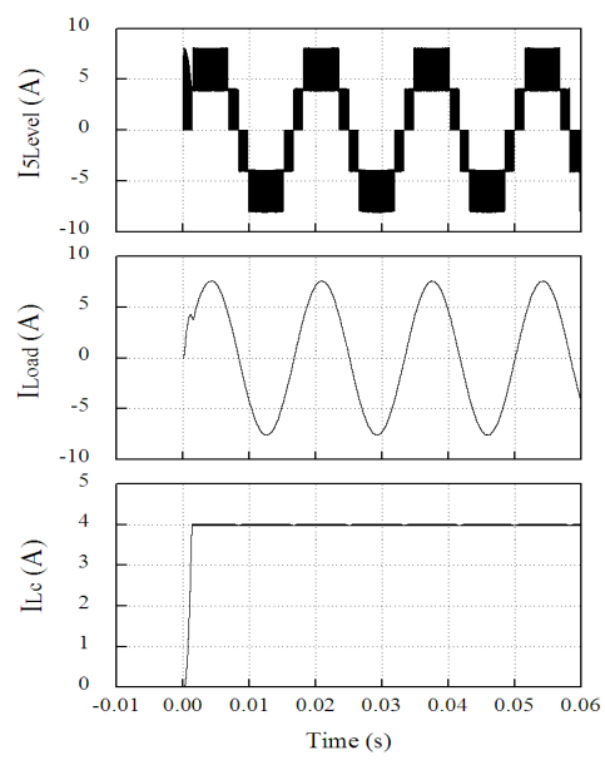

Figure 7. Output waveforms with hysteresis current controller: five-level, load current and inductor-cell current

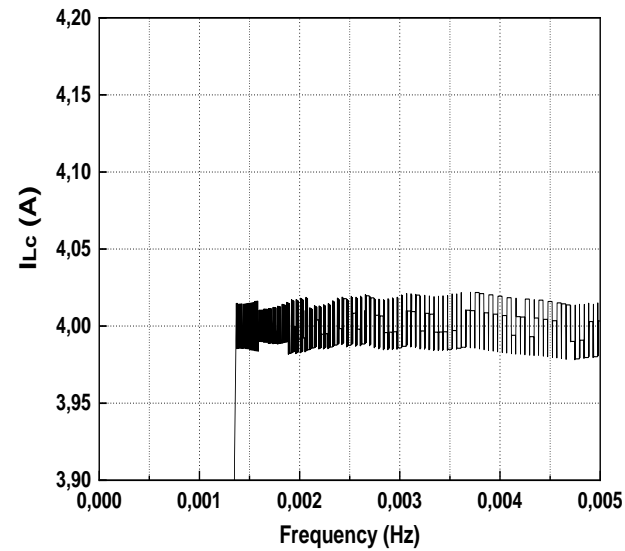

(a)

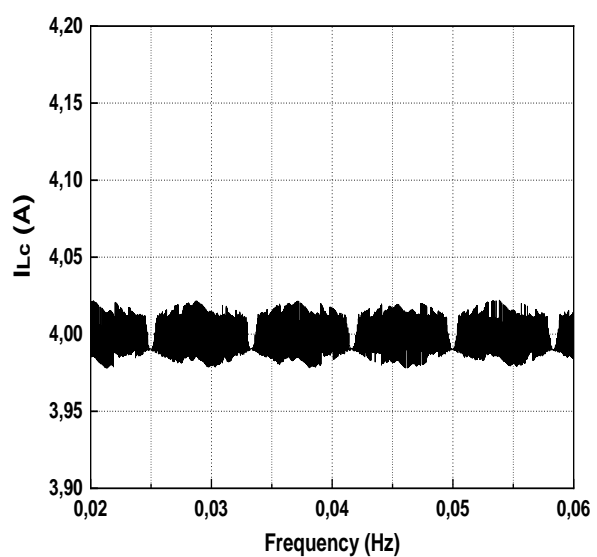

(b)

Figure 8. (a) Enlarged waveform of inductor cell current during starting, (b) enlarged current ripple

Figure 9 provides the harmonics analysis of the five-level PWM current in case of hysteresis current control. The highest magnitude of the harmonic component was the $7^{\text {th }}$ harmonic order. Its magnitude was about $0.1 \%$. All of low harmonics components were less than $0.1 \%$. The measured THD value for load current was $0.57 \%$. This value is also lower than the THD value using PI current controller. Further, Figure 10 presents output waveform results during load change test of inverter circuit. The resistance of power load was changed from $8 \Omega$ to be $16 \Omega$. As can be observed that even though the resistor load changed $100 \%$, it did not affect much to the inductor-cell current ripples. A relationship between THD of five-level PWM current for different values of dc input current is presented in Figure 11. The hysteresis current controller was able to make inverter circuit generating better quality of five-level current waveform. 


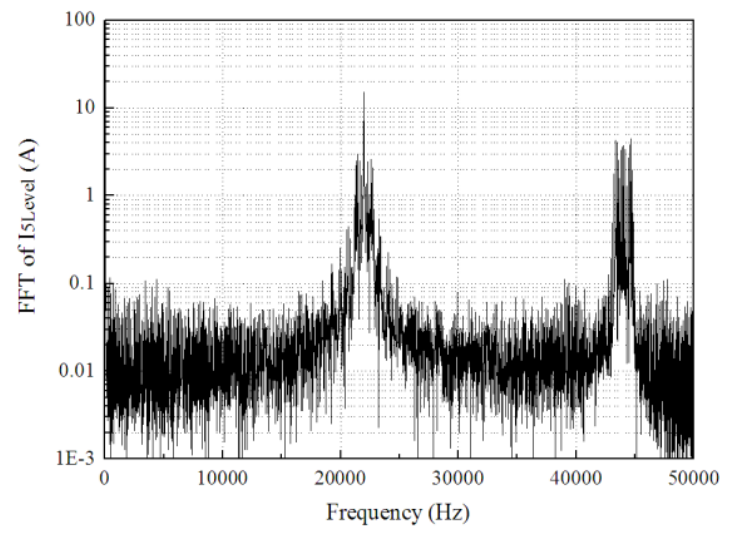

(a)

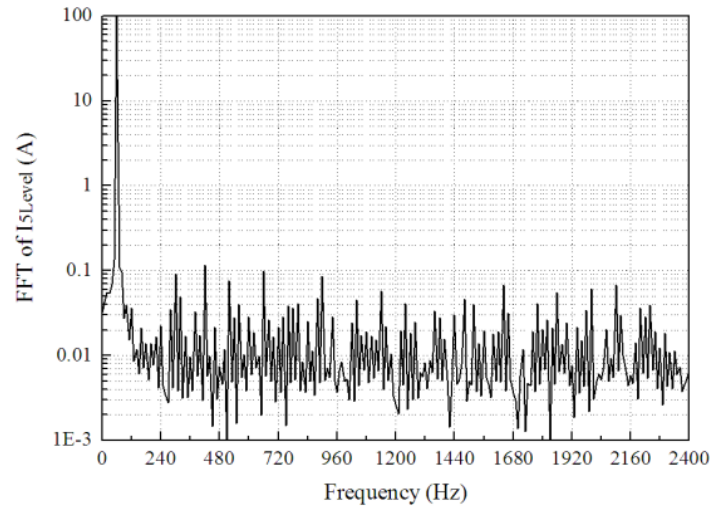

(b)

Figure 9. Harmonics magnitudes of five-level current with hysteresis controller: (a) frequency range 0-50 $\mathrm{kHz}$, (b) frequency range $0-240 \mathrm{~Hz}$

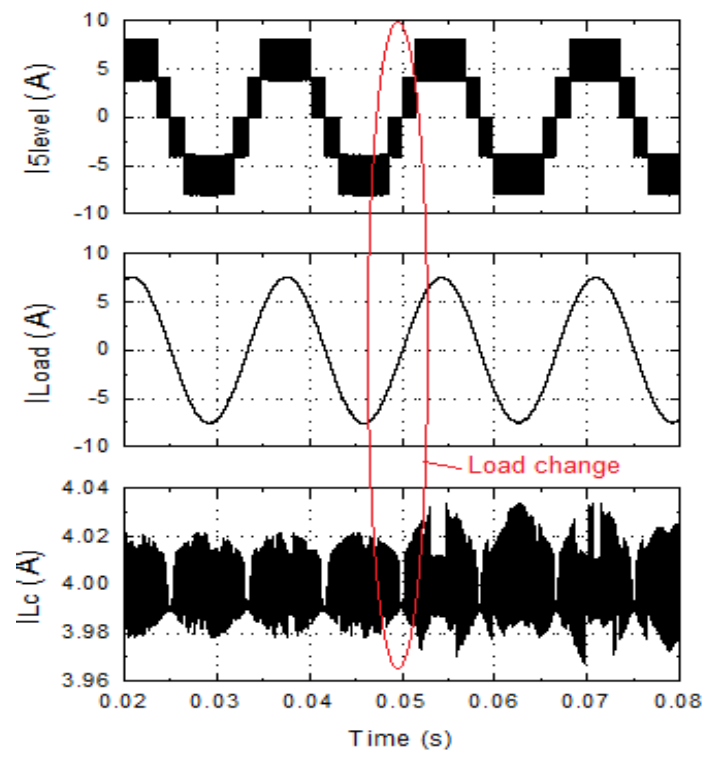

Figure 10. Current waveforms during load change test of inverter circuits with hysteresis controller

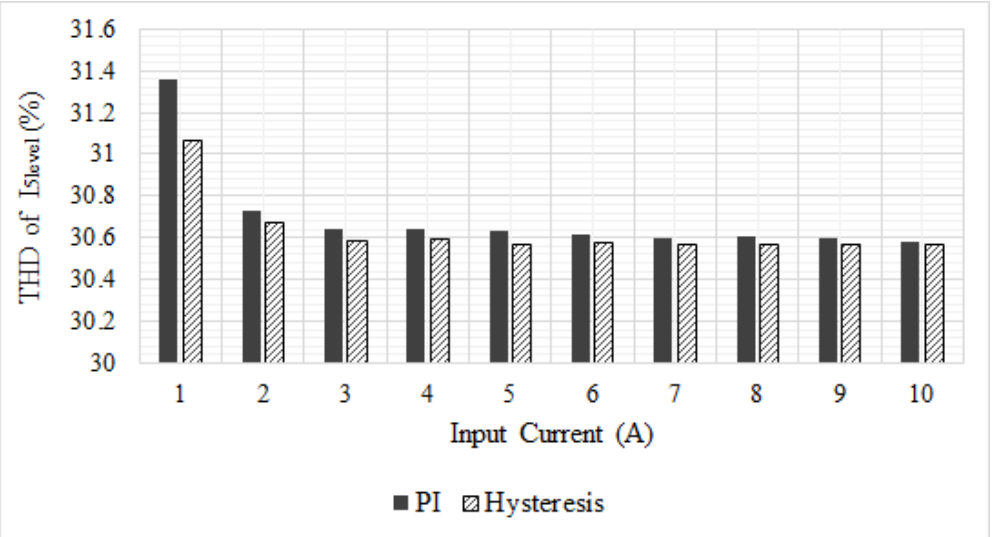

Figure 11. Relationship between THD of five-level current and magnitude of input current 


\section{CONCLUSION}

The paper discussed an application of hysteresis current controller for a five-level H-bridge with inductor-cell current source inverter. The controller governs the current in inductor cell to bear a five-level current waveform. A comparison to PI current controller, the hysteresis current controller had advantages related to smaller ripple, faster response, and lower magnitude of inductor-cell current during transient. Furthermore, it was also able to output a better ac current with lower harmonic contents. In case of response time, the hysteresis current controller was faster than the PI current controller. Both controllers were worked well controlling the inverter circuit to produce a five-level current waveform.

\section{REFERENCES}

[1] J. Rodiguez, J. S. Lai, and F. Z. Peng, "Multilevel inverter: a survey of topologies, controls, and application," IEEE Transactions on Industrial Electronics, vol. 49, no. 4, pp. 724-738, 2002.

[2] N. Vazquez, H. Lopez, C. Hernandez, E. Vazquez, R. Osorio, and J. Arau, "A different multilevel current source inverter", IEEE Transactions on Industrial Electronics, vol. 57, no. 8, pp. 2623 - 2632, 2010.

[3] J. Lai, and F. Z. Peng, "Multilevel converter-a new breed of power converters", IEEE Transactions on Industry Applications, vol. 32, no. 3, pp. 509-517, 1996

[4] Z H. Bai, and Z. C. Zhang, "Conformation of multilevel current source converter topologies using the duality principle," IEEE Transactions on Power Electronics, vol. 23, no. 5, pp. 2260-2267, 2008.

[5] F. L. M. Antunes, A. C. Braga, and I. Barbi. Application of a generalized current multilevel cell to current source inverters. IEEE Transactions on Power Electronics, vol. 46, no. 1, pp. 31-38, 1999.

[6] K. Gnanasambandam, A. K. Rathore, A. Edpuganti, D. Srinivasan, and J. Rodriguez, "Current-fed multilevel converters: an overview of circuit topologies, modulation techniques, and applications," IEEE Transactions on Power Electronics, vol. 32, no. 5, pp. 3382-3401, 2016.

[7] S. Kwak, and H. A. Toliyat, "Multilevel converter topology using two types of current-source inverters," IEEE Transactions on Industry Applications, vol. 42, no. 6, pp. 1558-1564, 2006.

[8] B. Wu, High power converters and AC drives. Piscataway, NJ: IEEE Press, 2017.

[9] B. Wu, J. Pontt, J. Rodriguez, S. Bernet, and S. Kouro, "Current-source converter and cycloconverter topologies for industrial medium-voltage drives," IEEE Transactions Industrial Electronics, vol. 55, no. 7, pp. 2786-2797, 2008.

[10] S. Kouro, J. Rodriguez, B. Wu, S. Bernet, and M. Perez, "Powering the future of industry: high-power adjustable speed drive topologies," IEEE Industry Application Magazine, vol. 18, no. 4, pp. 26-39, 2012.

[11] H. Lee, S. Jung, and S. Sul, "A current controller design for current source inverter-fed AC machine drive system," IEEE Transactions on Power Electronics, vol. 28, no. 3, pp. 1366-1381, 2012.

[12] S. A. Azmi, G. P. Adam, and B. Williams, "New direct regular-sampled pulse-width modulation applicable for grid and islanding operation of current source inverters," IET Power Electronics, vol. 7, no. 1, pp. 220-236, 2014.

[13] J. M. Carrasco, L. G. Franquelo, J. T. Bialasiewicz, E. Galván, R. C. Portillo Guisado, Ma. Ángeles Martín Prats, J. Ignacio León, and N. Moreno-Alfonso, "Power-electronic systems for the grid integration of renewable energy sources: a survey," IEEE Transactions on Industrial Electronics, vol. 53, no. 4, pp. 1002-1016, 2006.

[14] P. G. Barbosa, H. A. C. Braga, M. C. Barbosa, and E. C. Teixeria, "Boost current multilevel inverter and its application on single phase grid connected photovoltaic system," IEEE Transactions on Power Electronics, vol. 21, no. 4, pp. 1116-1124, 2006.

[15] L. S. Garcia, G. M. Buiatti, L. C. de Freitas, and E. A. A. Coelho, "Dual transformerless single-stage current source inverter with energy management control strategy," IEEE Transactions on Power Electronics, vol. 28, no. 10, pp 4644-4656, 2012.

[16] L. S. Garcia, H. J.Avelar, L. C. de Freitas, J. B.Vieira Jr., E. A. A.Coelho, V. J. Farias, and L. C. G Freitas, "Evaluation of a single-stage current source inverter with high voltage gain supplied by a PEM fuel cell," IET Power Electronics, vol. 5, no. 9, pp. 1834-1846, 2012.

[17] F. Blaabjerg, Z. Chen, and S. B. Kjaer, "Power electronics as efficient interface in dispersed power generation system," IEEE Transactions on Power Electronics, vol. 19, no. 5, pp. 1184-1194, 2004.

[18] Suroso, and T. Noguchi, "Multilevel current waveform generation using inductor cells and H-bridge current source inverter," IEEE Transactions on Power Electronics, vol. 27, no. 3, pp. 1090-1098, 2012.

[19] Suroso, D. T. Nugroho, and T. Noguchi, "A nine-level hybrid current source inverter using common-emitter topology and inductor-cell," International Journal of Power Electronics and Drive Systems, vol. 10, no. 2, pp. 852$859,2019$.

[20] T. Halkosaari, K. Kuusela, and H. Tuusa, "Effect of non-idealities on the performance of the 3-phase current source PWM converter," Proceeding of IEEE 32nd Annual Power Electronics Specialists Conference, pp. 654-659, 2001.

[21] Suroso and T. Noguchi, "A single-phase multilevel current-source converter using H-bridge and DC current modules," International Journal of Power Electronics and Drive System, vol. 4, no. 2, pp. 165-172, 2014.

[22] Suroso, and T. Noguchi, "Novel H-bridge multilevel current-source PWM inverter with inductor-cells," Conference Proceedings of IPEC, pp. 445-450, 2010.

[23] K. Iwaya, and T. Noguchi, "Novel current-source multilevel inverter driven by single gate drive power supply," Electrical Engineering in Japan, vol. 166, no. 2, pp. 10-16, 2010. 
[24] Suroso, A. N. Aziz, and T. Noguchi, "Five-level PWM inverter with a single DC power source for DC-AC power conversion," International Journal of Power Electronics and Drive Systems, vol. 8, no. 3, pp. 1230-1237, 2017.

[25] T. Noguchi, and Suroso, "New multilevel current-source PWM inverter with full-bridge inductor cells," IEEJ Transactions on Industry Applications, vol. 130, no. 6, pp. 808-815, 2010.

[26] T. Noguchi, and Suroso, "Review of novel multilevel current-source inverters with H-bridge and common-emitter based topologies," Proceedings of IEEE Energy Conversion Congress and Exposition, pp. 4006-4011, 2010.

[27] Suroso, D. T. Nugroho, and Winasis, "Three-level common-emitter current-source power inverter with simplified DC current-source generation," Journal of Engineering Science and Technology, vol. 13, no. 12, pp. 4027-4038, 2018.

[28] Y. L. Kameswari, and O. C. Sekhar, "Fuzzy logic controlled harmonic suppressor in cascaded multilevel inverter," International Journal of Power Electronics and Drive Systems, vol. 7, no. 2, pp. 303-310, 2016.

[29] Suroso and T. Noguchi, "A new three-level current-source PWM inverter and its application for grid connected power conditioner," Energy Conversion and Management, vol. 51, no. 7, pp. 1491-1499, 2010.

[30] J. Dao, D. Xu, and B. Wu, "A novel control scheme for current-source converter-based PMSG wind energy conversion systems," IEEE Transactions on Power Electronics, vol. 24, no. 4, pp. 963-972, 2009.

[31] H. Komurcugil, "Steady-state analysis and passivity-based control of single-phase PWM current-source inverters," IEEE Transactions on Industrial Electronics, vol. 57, no. 3, pp. 1026-1030, 2009.

[32] J. Dao, D. Xu, B. Wu, and N. R. Zargari, "Unified DC-link current control for low-voltage ride-through in currentsource-based wind energy conversion systems," IEEE Transactions on Power Electronics, vol. 26, no. 1, pp. 288297, 2011.

[33] S. Dong, Q. Zhang, S. Cheng, "Inductor current ripple comparison between ZSVM4 and ZSVM2 for Z-source inverters," IEEE Transactions on Power Electronics, vol. 31, no. 11, pp. 7592-7597, 2015.

[34] P. Karuppanan, "A novel adaptive-fuzzy hysteresis current controller-based active power line conditioners for power quality enhancement," International Journal of Power Electronics, vol. 5, no. 3/4, pp. 262-267, 2013.

[35] M. Della Krachai, K. Melouk, M. Keddar, "Investigating sine-band hysteresis control of photovoltaic-grid connected inverter," International Journal of Power Electronics and Drive System (IJPEDS), vol. 11, no. 2, pp. 969-976, 2020. 